\title{
DETECTION OF Bartonella henselae DNA IN CLINICAL SAMPLES INCLUDING PERIPHERAL BLOOD OF IMMUNE COMPETENT AND IMMUNE COMPROMISED PATIENTS BY THREE NESTED AMPLIFICATIONS
}

Karina Hatamoto KAWASATO(1), Léa Campos de OLIVEIRA(2), Paulo Eduardo Neves Ferreira VELHO(3), Lidia YAMAMOTO(4), Gilda Maria Barbaro DEL NEGRO(5) \& Thelma Suely OKAY(4)

\begin{abstract}
SUMMARY
Bacteria of the genus Bartonella are emerging pathogens detected in lymph node biopsies and aspirates probably caused by increased concentration of bacteria. Twenty-three samples of 18 patients with clinical, laboratory and/or epidemiological data suggesting bartonellosis were subjected to three nested amplifications targeting a fragment of the $60-\mathrm{kDa}$ heat shock protein (HSP), the internal transcribed spacer 16S-23S rRNA (ITS) and the cell division (FtsZ) of Bartonella henselae, in order to improve detection in clinical samples. In the first amplification 01, 04 and 05 samples, were positive by HSP (4.3\%), FtsZ (17.4\%) and ITS (21.7\%), respectively. After the second round six positive samples were identified by nested-HSP (26\%), eight by nested-ITS ( $34.8 \%$ ) and 18 by nested-FtsZ (78.2\%), corresponding to 10 peripheral blood samples, five lymph node biopsies, two skin biopsies and one lymph node aspirate. The nested-FtsZ was more sensitive than nested-HSP and nested-ITS $(\mathrm{p}<0.0001)$, enabling the detection of Bartonella henselae DNA in 15 of 18 patients (83.3\%). In this study, three nested-PCR that should be specific for Bartonella henselae amplification were developed, but only the nested-FtsZ did not amplify DNA from Bartonella quintana. We conclude that nested amplifications increased detection of $B$. henselae DNA, and that the nested-FtsZ was the most sensitive and the only specific to B. henselae in different biological samples. As all samples detected by nested-HSP and nested-ITS, were also by nested-FtsZ, we infer that in our series infections were caused by Bartonella henselae. The high number of positive blood samples draws attention to the use of this biological material in the investigation of bartonellosis, regardless of the immune status of patients. This fact is important in the case of critically ill patients and young children to avoid more invasive procedures such as lymph nodes biopsies and aspirates.
\end{abstract}

KEYWORDS: Bartonellosis; Bartonella spp.; Bartonella henselae; Cat Scratch Disease, PCR.

\section{INTRODUCTION}

Bacteria of the genus Bartonella are considered as emerging pathogens of increasing importance and worldwide distribution. The genus Bartonella includes at least 30 species and subspecies, and around 12 are human pathogens (BOULOUIS et al., 2005; LAMAS et al., 2008) responsible for syndromes such as Carrion's disease caused by Bartonella bacilliformis (nonexistent in non Andean countries), trench fever by Bartonella quintana, cat-scratch disease (CSD), bacillary angiomatosis, along with recurrent bacteremia, septicemia, endocarditis, trombocytopenic purpura, erythema multiforme, erythema nodosum, severe anemia and peliosis hepatis (BREITSCHWERDT et al., 2010). Bartonella henselae is the most frequently identified species in human infections (LAMAS et al., 2008; BREITSHWERDT et al., 2010).

Laboratory diagnosis is based on culture isolation, serology, histopathology, and molecular detection mainly in lymph node biopsies and aspirates, (which is probably due to a higher concentration of bacteria in these specimens), and more rarely in peripheral blood samples (HANSMANN et al., 2005; DEL PRETE et al., 2000; ARVAND \& SCHÄD, 2006). Species identification and differentiation is troublesome due to the bacteria's slow and fastidious growth. At the time of blood collection, the level of contamination is between 1 to 10 colony forming units/mL thus justifying the failure to isolate or amplify the bacterium DNA in blood samples after one-round amplifications (BRECHER et al., 2000). In our country, none of the few commercial kits, either serological or based on histochemical techniques, are currently available in routine laboratories.

Conventional one-round PCR targeting different Bartonella genes such as the $60 \mathrm{kDa}$ heat-shock protein (ANDERSON et al., 1994), the citrate synthase enzyme (NORMAN et al., 1995), the 16S rRNA (BIRTLES, 1995), the 16S-23S intergenic spacer (MINNICK \& BARBIAN, 1997) and the cell division protein FtsZ (KELLY et al, 1998) reported variable sensitivities, although some of the techniques were able to discriminate

(1) Clinical Laboratory, Children's Institute, Hospital das Clínicas da Faculdade de Medicina da Universidade de São Paulo, São Paulo, SP, Brazil. E-mail: karina.kawasato@ @icr.usp.br

(2) Medical Laboratory (LIM 03), Departamento de Patologia da Faculdade de Medicina da Universidade de São Paulo, São Paulo, SP, Brazil. E-mail: lealea@ uol.com.br

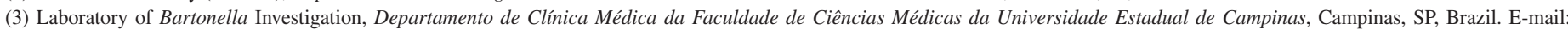
pvelho@unicamp.br

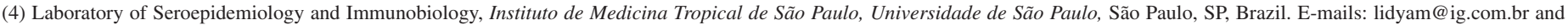
thelma.okay@usp.br

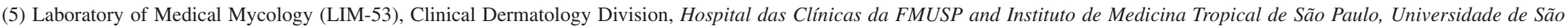
Paulo, São Paulo, SP, Brazil. E-mail: gildamdn@usp.br

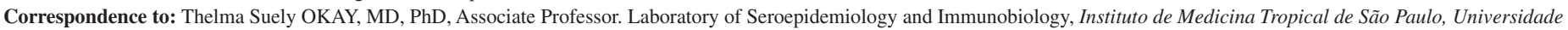
de São Paulo, Av. Dr. Enéas Carvalho de Aguiar 470, 05403-000 São Paulo, SP, Brazil. Phone: +55.11.3061 7022. Fax: + 55.11.3061 8270. E-mail: thelma.okay@usp.br 


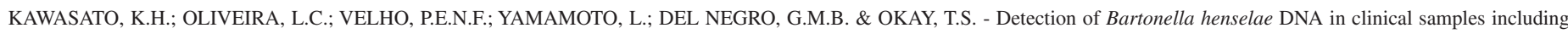
peripheral blood of immune competent and immune compromised patients by three nested amplifications. Rev. Inst. Med. Trop. Sao Paulo, 55(1): 1-6, 2013.

among species. More recently, a quantitative amplification targeting the Bartonella heat-shock protein groEL was used to investigate bacteremia levels in serum samples of 18 patients with CSD, however, positive results were detected in only three patients (VERMEULEN et al., 2008).

In the present study, we standardized three nested-PCR targeting the $60 \mathrm{kDa}$ heat-shock protein (ANDERSON et al., 1994), the FtsZ gene (KELLY et al., 1998) and the 16S-23S intergenic spacer (MINNICK \& BARBIAN, 1997) to improve $B$. henselae DNA detection in different biological specimen, including peripheral blood samples of immune competent and immune compromised patients.

\section{PATIENTS, MATERIAL, METHODS}

This research was approved by the Institutional Ethics Committee (CAPPesq protocol number 1245/2006). Informed consent was obtained from all patients, their parents, or legal guardians.

Twenty three samples from 18 patients with clinical and laboratory $(n=5)$, or only clinical and/or epidemiological suspicion of bartonellosis ( $n=13$ ) were tested: 13 blood samples, seven lymph node biopsies, two skin biopsies and one lymph node aspirate.

Three milliliters of EDTA whole blood samples or $10 \mathrm{mg}$ of skin, lymph node biopsies or aspirates were used for DNA extraction (QIAmp or DNeasy \& Tissue kit, QIAGEN Inc., USA), according to the manufacturer instructions.

Amplifications were performed following strict measures to minimize the risk of carry over contamination (BURKARDT, 2000). Briefly, reactions were set up in three separate rooms containing dedicated equipment, supplies and pipetting devices. Reagents and samples were handled with disposable gloves, DNA/RNase-free microtubes and pipetting tips in safety cabinets equipped with UV lights.

The outer primers (IDT, Iowa-USA) were designed elsewhere (ANDERSON et al., 1994; MINNICK AND BARBIAN, 1997; KELLY et al, 1998) and the inner primers were designed in our laboratory. The nested-HSP was performed with the primers forward 5'- AGCTGGTATCAAGGCAGGTG-3' and reverse 5'ATTTTCGTCTTCAGGCATCG-3' generating an amplification product of $184 \mathrm{bp}$; the nested-ITS was performed with the primers forward 5' - GAT GATGATCCCAAGCCTTC-3' and reverse 5' - TCCCC GGCATAATCTCATAA- 3'generating an amplification product of $113 \mathrm{bp}$, and the nested-FtsZ was performed with the primers forward 5'- CAAAACGGTTGGAGAGCAGT-3' and reverse 5'- CGCCTG TCATCTCATCAAGA-3' generating an amplification product of 218 bp. Amplifications were carried out in a T3 Thermocycler (Biometra, Göttingen, Germany), in a final volume of $50 \mu \mathrm{L}$ containing 1,000 ng of genomic DNA in the first round and $10 \mu \mathrm{L}$ were transferred onto the second round. Other reagent concentrations were: $200 \mu \mathrm{M}$ of dNTP (Labtrade, São Paulo, Brazil), 2.5 U of Taq DNA polymerase (Labtrade, São Paulo, Brazil), $1.5 \mathrm{mM}$ of $\mathrm{MgCl}_{2}$ and $0.4 \mu \mathrm{M}$ of each primer. Amplifications consisted of an initial denaturation step of five min at $95^{\circ} \mathrm{C}, 40$ cycles of one min at $95^{\circ} \mathrm{C}$, one min at $60^{\circ} \mathrm{C}$ for nested-HSP and nested-FtsZ or $55^{\circ} \mathrm{C}$ for the nested-ITS, one min at $72{ }^{\circ} \mathrm{C}$, ending with a final extension step of five min at $72^{\circ} \mathrm{C}$. PCR products were detected in $2 \%$ agarose gels stained with $0.5 \mu \mathrm{g} / \mathrm{mL}$ of ethidium bromide and perceived by UV transillumination (Vilber Lourmat, France). In each experiment, $B$. henselae DNA extracted from a purchased ATCC $49882^{\mathrm{R}}$ strain (Adolfo Lutz Institute, São Paulo, Brazil) was used as the positive control, and two sterile deionized water samples, representing the master mix and the DNA extraction room were used as negative controls.

To determine the detection limit, serial dilutions of $B$. henselae DNA, ranging from $1 \mathrm{ng}$ to $1 \mathrm{fg}$, were spiked with 1,000 ng of DNA from a healthy individual. Each dilution was tested 10 times to ensure reproducibility.

Microorganisms that can cause mononucleosis-like syndrome were included in the specificity evaluation because they can cause signs and symptoms that could be confused with the cat scratch disease or other acute infectious diseases: Escherichia coli, Streptococcus pyogenes, Staphylococcus epidermidis, Chlamydia pneumoniae, Mycobacterium tuberculosis, Cytomegalovirus, Epstein-Barr virus, Toxoplasma gondii, as well as four other Bartonella species: B. quintana, B. elizabethae, B. vinsonii and B. clarridgeiae. These microorganisms DNA were tested three times in different DNA concentrations (100 ng, $500 \mathrm{ng}$ and 1,000 ng).

Considering that a laboratory investigation of Bartonella spp. infection was performed in only five of the 18 patients, the confirmation of amplification results was made using RFLP and DNA sequencing, planning to adopt the RFLP as the standard confirmatory method in the future due to its better cost-effectiveness. In the case of nested-FtsZ, $4 \mu \mathrm{L}$ of the amplification products were digested with $5 \mathrm{U}$ of the restriction enzyme HpyCH4IV (New England Biolabs, Ipswich, USA) in a final volume of 20 $\mu \mathrm{L}$. After an incubation of three hours at $37^{\circ} \mathrm{C}$, the $B$. henselae amplification product (218 bp) should generate two fragments of 127 and $91 \mathrm{bp}$.

The entire nested-FtsZ product was purified (QIAquick PCR Purification Kit, QIAgen) and sequenced twice in each direction (ABI377, Applied Biosytems Incorporation, Foster City, California, USA). The degree of homology between amplified sequences and $B$. henselae Houston-1 strain (GenBank AF061746.1) was assessed by sequence alignment using the BLAST software available in http://www.ncbi.nlm. nih.gov/BLAST.

Sequence alignment was also used to ensure that the DNA sequence amplified by the nested-FtsZ did not present a significant degree of homology with the other Bartonella species: B. elizabethae (GenBank AF467760.1); B. vinsonii subsp berkoffii (GenBank AF467764.1); B. clarridgeiae (GenBank AF141018.1); B. rochalimae SM318006 (GenBank DQ676490.1) and B. rochalimae HUMBOLT 131 (GenBank DQ 676486.1).

Statistical analysis was performed by SPSS (version 13.0 for Windows, SPSS Inc; USA). The frequency of positive results was compared for each of the three systems after the first, and after the second round of amplification. Considering the three nested-PCR, the frequency of positive results was also compared. The agreement or disagreement of results was determined by the McNemar test and $p$ values $\leq 0.05$ were considered statistically significant. Bonferroni's correction was used for multiple comparisons $\left(p_{c}\right)$.

\section{RESULTS}

In the present study, three nested-FtsZ-PCR were developed to 


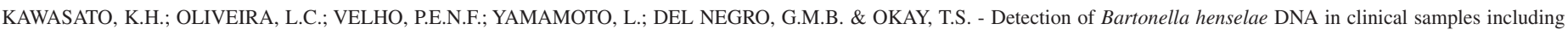
peripheral blood of immune competent and immune compromised patients by three nested amplifications. Rev. Inst. Med. Trop. Sao Paulo, 55(1): 1-6, 2013.

improve the molecular detection of Bartonella henselae in different biological samples, with emphasis on peripheral blood.

Twenty three samples from 18 patients were tested. Demographic data, signs and symptoms, laboratory tests results, antibiotic therapy and outcome of patients were summarized in Table 1. As an overview, 11 patients were female, ages varied from two to 80 years old, 15 had received antibiotics, 10 had a fever, 10 confirmed they had contact with cats, nine had adenomegaly, eight had underlying diseases, and in two patients the disease led to death. The cases of patients numbered 1 and 3 were reported elsewhere (VELHO et al., 2007; MAGALHÃES et al., 2010).

The limiting dilution test revealed that the first round of amplifications for each of the three systems (HSP, ITS and FtsZ) consistently detected $1 \mathrm{pg}$ of $B$. henselae DNA, and the second round $100 \mathrm{fg}$. There was no cross reactivity with the microorganisms used in the specificity tests, including DNA of other three species of Bartonella: elizabethae; vinsonii subsp berkoffi; clarridgeiae. However, the nested-HSP and the nestedITS yielded a positive, although weak, amplification when the higher concentration (1,000 ng) of Bartonella quintana was tested, even though the primers design was aimed at amplifying only the species henselae.
The first amplification was positive in one sample by HSP (1/23 or $4.3 \%$ ); in four samples by FtsZ (17.4\%), and in five samples by ITS $(21.7 \%)$. After the second round, there were six positive samples by nested-HSP (26\%), and eight by nested-ITS (34.8\%), while the nested-FtsZ was able to detect 18 samples (78.2\%): 10 peripheral blood samples, five lymph node biopsies, two skin biopsies and one lymph node aspirate. Statistical analysis comparing the frequency of positive results after the first and the second round of amplification confirmed that the nested amplification was worth performing only for the nested-FtsZ ( $4 / 23$ or $17.4 \%$ vs. $18 / 23$ or $78.3 \%$; $p=0.0001$ ), whereas there was no statistical significance for the nested-HSP $(p=0.063)$ or the nested-ITS $(p=0.250)$. Moreover, among the three amplification systems, the nested-FtsZ proved to be more sensitive than nested-HSP and ITS $(p<0.0001)$.

RFLP results after digestion of the FtsZ amplification products with the enzyme HpyCH4IV are displayed in Figure 1. As expected, all 18 positive samples generated two fragments of 127 and $91 \mathrm{bp}$.

In addition, automated DNA sequencing has confirmed RFLP results, i.e., the 18 amplification products were from the $B$. henselae FtsZ gene, as

TABLE 1

Demographic and epidemiological data, signs/symptoms, laboratory investigation, treatment and outcome of the 18 patients included in the study

\begin{tabular}{|c|c|c|c|c|c|c|c|c|}
\hline $\mathbf{N}^{\circ}$ & $\mathbf{A}$ & $\mathbf{G}$ & $\begin{array}{l}\text { Underlying } \\
\text { disease }\end{array}$ & $\begin{array}{l}\text { Signs, symptoms and } \\
\text { epidemiological data }\end{array}$ & $\begin{array}{l}\text { Samples } \\
\text { tested by } \\
\text { PCR }\end{array}$ & Laboratory investigation & Antibiotics & Outcome \\
\hline 1* & 36 & M & $\begin{array}{l}\text { Intravenous } \\
\text { drug addict, } \\
\text { AIDS }\end{array}$ & $\begin{array}{l}\text { Fever. pulmonary edema, } \\
\text { bacillary angiomatosis, } \\
\text { severe anemia, hepatitis, } \\
\text { peritonitis, pleuritis, peri- } \\
\text { carditis, perianal lesion, } \\
\text { and skin papule. Contact } \\
\text { with cats and dogs. }\end{array}$ & $\begin{array}{l}\text { skin } \\
\text { biopsy } \\
\text { (papule) }\end{array}$ & $\begin{array}{l}\text { Electron microscopy of the papule } \\
\text { biopsy showed a double-layered- } \\
\text { bacterium adhered to an erythrocyte. } \\
\text { Histopathology was suggestive of } \\
\text { Bartonella spp. Negative blood } \\
\text { and skin cultures. Negative anti- } B \text {. } \\
\text { henselae and } B \text {. quintana serology } \\
\text { (IFAT-IgG). Positive PCR of the } \\
\text { papule. DNA sequencing confirmed } \\
\text { that PCR amplified } B \text {. henselae DNA. }\end{array}$ & clarithromycin & $\begin{array}{l}\text { Recovery of } \\
\text { acute symptoms. } \\
\text { The patient } \\
\text { moved to } \\
\text { another state and } \\
\text { he was lost to } \\
\text { follow-up. }\end{array}$ \\
\hline 2 & 14 & $\mathrm{~F}$ & none & $\begin{array}{l}\text { No fever. Angio- } \\
\text { proliferative skin lesion. } \\
\text { Contact with cats. }\end{array}$ & blood & $\begin{array}{l}\text { Electron microscopy of the skin biopsy } \\
\text { showed a double-layered-bacteria } \\
\text { adhered to erytrocytes, Positive anti- } \\
\text { Bartonella } \operatorname{IgG}(\text { IFAT). The blood } \\
\text { sample yielded a positive nested-FtsZ- } \\
\text { PCR. The skin lesion was not tested by } \\
\text { nested-FtsZ-PCR }\end{array}$ & Erythromycin & Full recovery \\
\hline$* 3$ & 27 & $\mathrm{~F}$ & none & $\begin{array}{l}\text { Asymptomatic. Had do- } \\
\text { nated blood (Public Blood } \\
\text { Bank). Contact with cats. } \\
\text { This woman is the mother } \\
\text { of patient number } 4 \text {. }\end{array}$ & Blood & $\begin{array}{l}\text { Optical microscopy of the erythrocytes } \\
\text { from the blood bag showing bacteria } \\
\text { adhered to erythrocytes. Blood was } \\
\text { positive by nested-FtsZ-PCR. }\end{array}$ & None & $\begin{array}{l}\text { Outpatient clinic } \\
\text { follow-up with } \\
\text { negative nested- } \\
\text { FtsZ-PCR in } \\
\text { peripheral blood } \\
\text { after six months }\end{array}$ \\
\hline 4 & 3 & $\mathrm{~F}$ & $\begin{array}{l}\text { Neonatal } \\
\text { cholestasis } \\
\text { syndrome }\end{array}$ & $\begin{array}{l}\text { No fever. anemia, jaun- } \\
\text { dice, hepatosplenomegaly. } \\
\text { Contact with cats. }\end{array}$ & Blood & $\begin{array}{l}\text { IFAT -IgG was negative for Bartonella } \\
\text { henselae and B. quintana. Electron mi- } \\
\text { croscopy showed double layered- bac- } \\
\text { teria adhered to erythrocytes. The child } \\
\text { peripheral blood at three years old was } \\
\text { positive by nested-FtsZ-PCR. }\end{array}$ & $\begin{array}{l}\text { Erythromycin, } \\
\text { gentamycin and } \\
\text { azythromycin }\end{array}$ & $\begin{array}{l}\text { Improvement } \\
\text { of infection and } \\
\text { outpatient clinic } \\
\text { follow-up }\end{array}$ \\
\hline
\end{tabular}




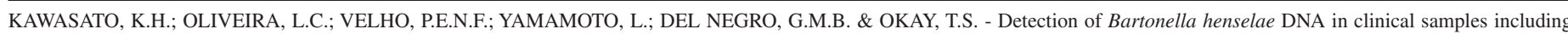
peripheral blood of immune competent and immune compromised patients by three nested amplifications. Rev. Inst. Med. Trop. Sao Paulo, 55(1): 1-6, 2013.

TABLE 1

Demographic and epidemiological data, signs/symptoms, laboratory investigation, treatment and outcome of the 18 patients included in the study (continuation)

\begin{tabular}{|c|c|c|c|c|c|c|c|c|}
\hline $\mathbf{N}^{\circ}$ & $\mathbf{A}$ & $\mathbf{G}$ & $\begin{array}{l}\text { Underlying } \\
\text { disease }\end{array}$ & $\begin{array}{l}\text { Signs, symptoms and } \\
\text { epidemiological data }\end{array}$ & $\begin{array}{l}\text { Samples } \\
\text { tested by } \\
\text { PCR }\end{array}$ & Laboratory investigation & Antibiotics & Outcome \\
\hline 5 & 11 & M & None & Fever, hepatomegaly & Blood & $\begin{array}{l}\text { Blood culture identified Bartonella } \\
\text { spp. Peripheral blood was positive by } \\
\text { nested-FtsZ-PCR. }\end{array}$ & $\begin{array}{l}\text { Amikacin and } \\
\text { cefotaxime }\end{array}$ & Full recovery \\
\hline 6 & 5 & M & None & $\begin{array}{l}\text { Fever, cervical adeno- } \\
\text { megaly. }\end{array}$ & $\begin{array}{l}\text { Lymph } \\
\text { node } \\
\text { biopsy, } \\
\text { blood }\end{array}$ & $\begin{array}{l}\text { Lymph node biopsy and peripheral } \\
\text { blood were positive by nested-FtsZ- } \\
\text { PCR. }\end{array}$ & Cotrimoxazole & Full recovery \\
\hline 7 & 5 & M & None & $\begin{array}{l}\text { Fever, axillary adenomega- } \\
\text { ly. Contact with cats. }\end{array}$ & Blood & $\begin{array}{l}\text { Peripheral blood was positive by } \\
\text { nested-FtsZ-PCR. }\end{array}$ & Cotrimoxazole & Full recovery \\
\hline 8 & 9 & $\mathrm{~F}$ & None & $\begin{array}{l}\text { High fever for } 3 \text { months } \\
\text { and cervical adenomegaly. }\end{array}$ & $\begin{array}{l}\text { Lymph } \\
\text { node } \\
\text { biopsy }\end{array}$ & $\begin{array}{l}\text { Lymph node biopsy was positive by } \\
\text { nested-FtsZ-PCR }\end{array}$ & Claritromicin & Full recovery \\
\hline 9 & 8 & $\mathrm{~F}$ & None & $\begin{array}{l}\text { No fever, cervical adeno- } \\
\text { megaly. Contact with cats. }\end{array}$ & $\begin{array}{l}\text { Lymph } \\
\text { node } \\
\text { aspirate }\end{array}$ & $\begin{array}{l}\text { Lymph node aspirate was positive by } \\
\text { nested-FtsZ-PCR. }\end{array}$ & None & Full recovery \\
\hline 10 & 9 & $\mathrm{~F}$ & None & $\begin{array}{l}\text { Fever, contact with cats } \\
\text { and cat scratch }\end{array}$ & $\begin{array}{l}\text { Lymph } \\
\text { node } \\
\text { biopsy, } \\
\text { blood }\end{array}$ & $\begin{array}{l}\text { Lymph node biopsy and peripheral } \\
\text { blood were positive by nested-FtsZ- } \\
\text { PCR. }\end{array}$ & $\begin{array}{l}\text { Cotrimoxazole } \\
\text { Cefalexin }\end{array}$ & Full recovery \\
\hline 11 & 6 & $\mathrm{~F}$ & None & $\begin{array}{l}\text { Fever, Contact with cats. } \\
\text { and antecedent of cat } \\
\text { scratch two months before }\end{array}$ & Blood & $\begin{array}{l}\text { Peripheral blood was positive by } \\
\text { nested-FtsZ-PCR. }\end{array}$ & Cotrimoxazole & Full recovery \\
\hline 12 & 12 & M & None & $\begin{array}{l}\text { No fever, cervical adeno- } \\
\text { megaly. }\end{array}$ & $\begin{array}{l}\text { Lymph } \\
\text { node } \\
\text { biopsy }\end{array}$ & $\begin{array}{l}\text { Lymph node biopsy was positive by } \\
\text { nested-FtsZ-PCR }\end{array}$ & Cotrimoxazole & Full recovery \\
\hline 13 & 9 & $\mathrm{~F}$ & $\begin{array}{l}\text { Meningo en- } \\
\text { cephalitis and } \\
\text { seizures. }\end{array}$ & $\begin{array}{l}\text { Two months of fever and } \\
\text { daxillary adenomegaly. } \\
\text { Contact with cats. }\end{array}$ & Blood & $\begin{array}{l}\text { Peripheral blood was positive by } \\
\text { nested-FtsZ-PCR. }\end{array}$ & $\begin{array}{l}\text { Amoxycillin, } \\
\text { cefalexin, } \\
\text { erythromycin }\end{array}$ & Full recovery \\
\hline 14 & 7 & M & $\begin{array}{l}\text { AIDS, pelio- } \\
\text { sis hepatis }\end{array}$ & $\begin{array}{l}\text { High and persistent fever, } \\
\text { negative blood, urine and } \\
\text { CSF cultures. }\end{array}$ & $\begin{array}{l}\text { Skin } \\
\text { biopsy }\end{array}$ & $\begin{array}{l}\text { Skin biopsy was positive by nested- } \\
\text { FtsZ-PCR. }\end{array}$ & $\begin{array}{l}\text { Vancomycin, } \\
\text { clindamycin and } \\
\text { doxycycline }\end{array}$ & Death \\
\hline 15 & 12 & M & $\begin{array}{l}\text { Chronic } \\
\text { Granuloma- } \\
\text { tous Disease }\end{array}$ & $\begin{array}{l}\text { No fever, cervical adeno- } \\
\text { megaly. }\end{array}$ & $\begin{array}{l}\text { Lymph } \\
\text { node bi- } \\
\text { opsy, and } \\
\text { blood }\end{array}$ & $\begin{array}{l}\text { Lymph node biopsy and peripheral } \\
\text { blood were positive by nested-FtsZ- } \\
\text { PCR. }\end{array}$ & Cefalexin & Death \\
\hline 16 & 61 & $\mathrm{~F}$ & $\begin{array}{l}\text { Hodgkin } \\
\text { lymphoma }\end{array}$ & $\begin{array}{l}\text { No fever. Cervical and } \\
\text { inguinal adenomegaly. } \\
\text { Contact with cats }\end{array}$ & $\begin{array}{l}\text { Lymph } \\
\text { node } \\
\text { biopsy, } \\
\text { blood }\end{array}$ & $\begin{array}{l}\text { Lymph node biopsy and peripheral } \\
\text { blood were negative by nested-FtsZ- } \\
\text { PCR. }\end{array}$ & None & $\begin{array}{l}\text { Improvement } \\
\text { of symptoms, } \\
\text { under chemo- } \\
\text { therapy }\end{array}$ \\
\hline 17 & 80 & $\mathrm{~F}$ & $\begin{array}{l}\text { Non-Hodgkin } \\
\text { lymphoma }\end{array}$ & $\begin{array}{l}\text { nNo fever. Cervical adeno- } \\
\text { megaly, pneumonia and } \\
\text { pleural effusion }\end{array}$ & $\begin{array}{l}\text { Lymph } \\
\text { node bi- } \\
\text { opsy and } \\
\text { blood }\end{array}$ & $\begin{array}{l}\text { Lymph node biopsy and peripheral } \\
\text { blood were negative by nested-FtsZ- } \\
\text { PCR. }\end{array}$ & Ciprofloxacin & $\begin{array}{l}\text { Improvement } \\
\text { of symptoms, } \\
\text { under chemo- } \\
\text { therapy }\end{array}$ \\
\hline 18 & 2 & $\mathrm{~F}$ & $\begin{array}{l}\text { Liver insuffi- } \\
\text { ciency, porto- } \\
\text { pulmonary } \\
\text { hypertension }\end{array}$ & & Blood & $\begin{array}{l}\text { Staphylococcus coagulase negative } \\
\text { was isolated from blood. Peripheral } \\
\text { blood sample was negative by nested- } \\
\text { FtsZ-PCR. }\end{array}$ & Cefepim & $\begin{array}{l}\text { Improvement } \\
\text { of symptoms. } \\
\text { Outpatient clinic } \\
\text { follow-up. }\end{array}$ \\
\hline
\end{tabular}

$\mathrm{A}=$ age in years; $\mathrm{G}=$ gender (masculine or feminine). * reference VELHO et al., 2007 (case No. 1) and MAGALHÃES et al., 2010 (case No. 3). 


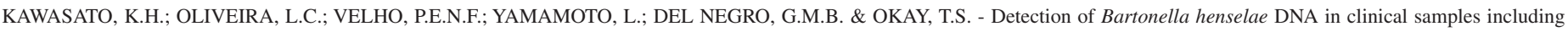
peripheral blood of immune competent and immune compromised patients by three nested amplifications. Rev. Inst. Med. Trop. Sao Paulo, 55(1): 1-6, 2013.

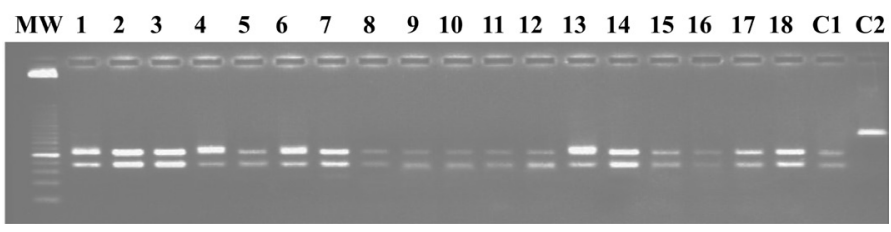

Fig. 1 - RFLP of the 18 positive nested-FtsZ-PCR samples (10 blood samples, 5 lymph node biopsies, 2 lymph node aspirates and 1 skin biopsy) after digestion with HpyCH4IV (lanes 1 to 18). The molecular weight marker (MW) is the 25 base-pair ladder (Invitrogen) and the strongest band is 125 base-pairs. C1 displays the amplification product of the Houston-1 strain after digestion (positive control), generating two fragments of 127 and 91 base-pairs, like the 18 positive samples of the study, and $\mathrm{C} 2$ exhibits the same positive control prior to HpyCH4IV digestion showing the entire fragment of 218 base-pairs.

the degree of homology between these $18 \mathrm{PCR}$ products and $B$. henselae Houston-1 strain varied from 97 to $100 \%$ (data not shown).

\section{DISCUSSION}

Bartonella spp. isolation and specific IgG detection is available in just a few university centers in our country, and therefore in most cases the diagnosis of bartonellosis is based on the association of suggestive signs and symptoms with at least one of the following parameters: epidemiological data reporting contact with animals, especially cats; microscopy and/or histological findings (HANSMANN et al., 2005).

Due to the fact that our patients live in areas with low levels of laboratory resources, in a significant amount of cases none of the specific tests to diagnose Bartonella spp. infections were performed. In order to circumvent the lack of a gold standard in these cases, we confirmed that the nested-FtsZ amplifications corresponded to $B$. henselae DNA by using RFLP and DNA sequencing. Due to budget constraints, we did not sequence the six nested-HSP positive samples and the eight nested-ITS ones.

It is known that the target gene, the type of biological sample, the sample size as well as different DNA extraction protocols can dramatically influence amplification results. Only a few studies have reported detection of Bartonella spp. DNA in blood samples of CSD or immune compromised patients (ARVAND \& SCHÄND, 2006; VELHO et al., 2007), while the detection in serum samples has so far been unsuccessful (VERMEULEN et al., 2008).

Although the HSP gene primers had already been used to amplify lymph node biopsies and secretions by ANDERSON et al. (1994); AVIDOR et al. (1997) and HANSMANN et al. (2005) with detection rates varying from 69 to $84 \%$, our nested-HSP was the least sensitive of the three systems, and yielded positive results with $B$. quintana DNA, even though the primers were designed to amplify only $B$. henselae.

GARCIA-ESTEBAN et al. (2008) reported the detection of Bartonella by a 16S-23S rRNA intergenic spacer and a multiplex-PCR targeting the $16 \mathrm{~S}$ rRNA gene combined with a reverse line blotting that could simultaneously detect around 20 different Bartonella species from a number of clinical specimens. In the present study, despite the use of a new set of primers of the 16S-23S rRNA intergenic spacer in nested amplifications, the sensitivity was low, and there was cross-reactivity with $B$. quintana DNA, as in the case of the nested-HSP amplifications.
EHRENBORG et al. (2000) used different primers of B. henselae FtsZ gene in one-round amplifications. They tested 15 biological specimens including tissue fragments and blood samples from cats and humans, either HIV-positive or with no underlying conditions, and found a positivity of $64 \%$.

The C-terminal end of the FtsZ gene was used to investigate the presence of Bartonella spp. DNA in 80 samples (lymph node biopsies, lymph node aspirates, heart valve fragments) of patients with CSD and/ or endocarditis by a one-round PCR. They detected 35 positive samples (43.75\%) in comparison with 39 positive samples (48.75\%) by ITS or pap31 one-round amplifications (ZEAITER et al., 2002). In the present study, the same FtsZ gene region was used to test 23 samples of 18 patients, 15 of whom had already received antibiotics, but even so the nested-FtsZ-PCR was positive in 18 samples of 15 patients. ARVAND $\&$ SCHÄD (2006) reported detection of $B$. henselae DNA in a child with CSD up to nine weeks after admission and three weeks of antibiotic therapy. In this child several blood samples were tested, and they used a semi-nested PCR targeting the $B$. henselae htrA gene.

Among the five patients with laboratory evidence of Bartonella spp. infection (1-5, Table 1), PCR confirmed the diagnosis in all of them (four blood samples and one skin biopsy). Patient number one had AIDS and patient number 4 was a three year old child with an antecedent of neonatal cholestasis syndrome, while the other three patients had no underlying conditions.

The two skin biopsies analyzed in the present study were positive by PCR and belonged to AIDS patients (Table 1, number 1 and 14). With regards to the seven lymph node biopsies, PCR was positive in five, and only one of seven patients (number 15) had a previous medical condition. In two patients only the lymph node biopsy was analyzed (number 8 and 12 ), and in three patients blood samples were tested in parallel and all specimens were positive (number 6, 10 and 15).

As for the 13 blood samples analyzed in the study, 10 were positive (seven of 10 patients had no underlying conditions). The three negative blood samples belonged to patients 16 and 17, who were later diagnosed with lymphoma, and to patient number 18 who had a staphylococcal infection detected by blood culture. Nevertheless, considering that our nested-FtsZ is species-specific, it is not possible to rule out the presence of other Bartonella species in these patients.

We conclude that nested amplifications increased the detection of $B$. henselae DNA, and that nested-FtsZ was the most sensitive and the only one specific to $B$. henselae in different biological specimens. Taking into account that all samples detected by nested-HSP and nested-ITS were also detected by the nested-FtsZ, and that the 18 positive samples presented with highly homologous nucleotide sequences in comparison with Bartonella henselae Houston-1 strain, we infer that in our series all infections were caused by Bartonella henselae. The high positivity of blood samples has highlighted the use of this biological material to investigate bartonellosis irrespective of the patients' immune status. This is of great importance in critically ill patients and in young children where this method can be used in order to avoid more invasive procedures such as lymph node biopsies and fine-needle aspirates. Considering that nested-amplifications are more prone to carry-over contamination, we intend to develop a quantitative diagnostic tool based on the primers presented herewith. 
KAWASATO, K.H.; OLIVEIRA, L.C.; VELHO, P.E.N.F.; YAMAMOTO, L.; DEL NEGRO, G.M.B. \& OKAY, T.S. - Detection of Bartonella henselae DNA in clinical samples including peripheral blood of immune competent and immune compromised patients by three nested amplifications. Rev. Inst. Med. Trop. Sao Paulo, 55(1): 1-6, 2013.

\section{RESUMO}

\section{Detecção de DNA de Bartonella henselae em amostras clínicas, incluindo sangue periférico, de pacientes imunocompetentes e imunodeprimidos por meio de três amplificações duplas}

Bactérias do gênero Bartonella constituem patógenos emergentes detectados em biópsias de linfonodos e secreções de gânglios provavelmente devido a maior concentração de bactérias. Vinte e três amostras de 18 pacientes com dados clínicos, laboratoriais e/ou epidemiológicos sugestivos de bartonelose foram submetidas a três amplificações duplas para a detecção de fragmento da proteína de choque térmico de 60-kDa (HSP), do espaçador interno 16S-23S rRNA (ITS) e da proteína de divisão celular (FtsZ) de Bartonella henselae, para melhorar a detecção em amostras clínicas. Na primeira amplificação, uma, quatro e cinco amostras, respectivamente, foram positivas pelo HSP (4,3\%), FtsZ $(17,4 \%)$ e pelo ITS $(21,7 \%)$. Com a segunda amplificação foram identificadas seis amostras positivas pelo nested-HSP (26\%), oito pelo nested-ITS $(34,8 \%)$ e 18 pelo nested- FtsZ (78,2\%), correspondentes a 10 amostras de sangue periférico, cinco biópsias de linfonodos, duas biópsias de pele e um aspirado de gânglio. A nested-FtsZ foi mais sensível que a nested-HSP e a nested-ITS ( $p<0,0001)$, possibilitando a detecção de DNA de Bartonella henselae em 15 de 18 pacientes (83,3\%). No presente estudo, três nested-PCR, consideradas específicas para a amplificação da Bartonella henselae, foram desenvolvidas, porém somente a nestedFtsZ não amplificou o DNA de Bartonella quintana. Concluímos que amplificações duplas aumentaram a detecção de DNA de $B$. henselae, e que a nested-FtsZ foi a mais sensível e a única específica para $B$. henselae em diferentes amostras biológicas. Como todas as amostras detectadas pelo HSP-nested e nested-ITS foram também pela nested-FtsZ, inferimos que, em nossa casuística, as infecções foram causadas por Bartonella henselae. A elevada positividade de amostras de sangue chamou a atenção para a utilização deste material biológico na investigação de bartoneloses, independentemente do estado imune dos pacientes. Este fato é importante no caso de pacientes criticamente enfermos e crianças pequenas para evitar procedimentos mais invasivos, como biópsias e punções de gânglios.

\section{ACKNOWLEDGMENTS}

We thank the DASA laboratory; the Microbiology Division of the Central Laboratory of the Hospital das Clínicas da Faculdade de Medicina da Universidade de São Paulo, the Virology Laboratory and the Protozoology Laboratory of the Institute of Tropical Medicine of São Paulo, and the Adolfo Lutz Institute (São Paulo) that have generously provided the strains used in the specificity tests. We are also grateful for the technical assistance of Ms. Adriana Fumie Tateno (Virology Laboratory) on the DNA sequencing.

\section{REFERENCES}

1. Anderson B, Sims K, Regnery R, Robinson L, Schmidt MJ, Goral S, et al. Detection of Rochalimaea henselae DNA in specimens from cat scratch disease patients by PCR. J Clin Microbiol. 1994;32:942-8.

2. Arvand M, Schäd SG. Isolation of Bartonella henselae DNA from the peripheral blood of a patient with cat scratch disease up to 4 months after the cat scratch injury. J Clin Microbiol. 2006;44:2288-90.
3. Avidor B, Kletter Y, Abulafia S, Golan Y, Ephros M, Giladi M. Molecular diagnosis of cat scratch disease: a two-step approach. J Clin Microbiol. 1997;35:1924-30.

4. Birtles RJ. Differentiation of Bartonella species using restriction endonuclease analysis of PCR amplified 16S rRNA genes. FEMS Microbiol Lett. 1995;129:261-5.

5. Boulouis HJ, Chang C, Henn J, Kasten RW, Chomel BB. Factors associated with the rapid emergence of zoonotic Bartonella infections. Vet Res. 2005;36:383-410.

6. Brecher ME, Holland PV, Pineda AA, Tegtmeier GE, Yomtovian R. Growth of bacteria in inoculated platelets: implications for bacteria detection and the extension of platelet storage. Transfusion. 2000;40:1308-12.

7. Breitschwerdt EB, Maggi RG, Chomel BB, Lappin MR. Bartonellosis: an emerging infectious disease of zoonotic importance to animals and human beings. J Vet Emerg Crit Care (San Antonio). 2010;20:8-30

8. Burkardt, HJ. Standardization and quality control of PCR analyses. Clin Chem Lab Med. 2000;38:87-91

9. Del Prete R, Fumarola D, Ungari S, Fumarola L, Miragliotta G. Polymerase chain reaction detection of Bartonella henselae bacteraemia in an immunocompetent child with cat-scratch disease. Eur J Pediatr. 2000;159:356-9.

10. Ehrenborg C, Wesslén L, Jakobson A, Friman G, Holmberg M. Sequence variation in the $f t s \mathrm{Z}$ gene of Bartonella henselae isolates and clinical samples. J Clin Microbiol. 2000;38:682-7.

11. García-Esteban C, Gil H, Rodríguez-Vargas M, Gerrikagoitia X, Barandika J, Escudero R, et al. Molecular method for Bartonella species identification in clinical and environmental samples. J Clin Microbiol. 2008;46:776-9.

12. Hansmann Y, DeMartino S, Piémont Y, Meyer N, Mariet P, Heller R, et al. Diagnosis of cat scratch disease with detection of Bartonella henselae by PCR: a study of patients with lymph node enlargement. J Clin Microbiol. 2005;43:3800-6.

13. Kelly TM, Padmalayam I, Baumstark BR. Use of the cell division protein FtsZ as a means of differentiating among Bartonella species. Clin Diagn Lab Immunol. 1998;5:766-72.

14. Lamas C, Curi A, Bóia M, Lemos E. Human bartonellosis: seroepidemiological and clinical features with an emphasis on data from Brazil. A Review. Mem Inst Oswaldo Cruz. 2008;103:221-35.

15. Magalhães RF, Cintra ML, Barjas-Castro ML, Del Negro GM, Okay TS, Velho PE. Blood donor infected with Bartonella henselae. Transfus Med. 2010;20:280-2.

16. Minnick, MF, Barbian, KD. Identification of Bartonella using PCR; genus - and species-specific primer sets. J Microbiol Methods. 1997;31:51-7.

17. Norman AF, Regnery R, Jameson P, Greene C, Krause D. Differentiation of Bartonella-like isolation at the species level by PCR-restriction fragment length polymorphism in the citrate synthase gene. J Clin Microbiol. 1995;33:1797-803.

18. Velho PE, Pimentel V, Del Negro GM, Okay TS, Diniz PP, Breitschwerdt EB. Severe anemia, panserositis, and cryptogenic hepatitis in an HIV patient infected with Bartonella henselae. Ultrastruct Pathol. 2007;31:373-7.

19. Vermeulen MJ, Diederen BM, Verbakel H, Peeters MF. Low sensitivity of Bartonella henselae PCR in serum samples of patients with cat-scratch disease lymphadenitis. J Med Microbiol. 2008;57:1049-50.

20. Zeaiter Z, Liang Z, Raoult D. Genetic classification and differentiation of Bartonella species based on comparison of partial fts $Z$ gene sequences. J Clin Microbiol. 2002;40:3641-7.

Received: 26 March 2012

Accepted: 20 August 2012 